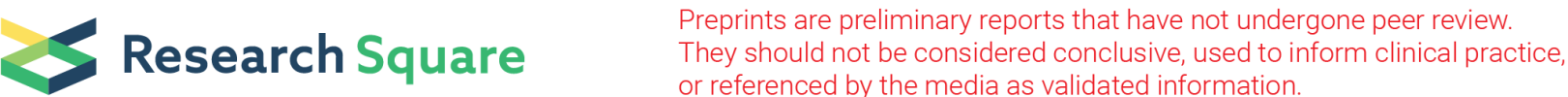

\section{A 95-gene Signature Stratifies Recurrence Risk of Invasive Disease in ER-positive, HER2-negative, Node-negative Breast Cancer With Intermediate 21- gene Signature Recurrence Scores}

\section{Takeo Fujii}

The University of Texas MD Anderson Cancer Center

Hiroko Masuda

Showa University - Hatanodai Campus: Showa Daigaku

Yee Chung Cheng

Medical College of Wisconsin Cancer Center

Fei Yang

The University of Texas MD Anderson Cancer Center

Aysegul A. Sahin

The University of Texas MD Anderson Cancer Center

Yasuto Naoi

Osaka University Faculty of Medicine Graduate School of Medicine: Osaka Daigaku Daigakuin Igakukei

Kenkyuka Igakubu

Yuki Matsunaga

Showa University - Hatanodai Campus: Showa Daigaku

Akshara Raghavendra

The University of Texas MD Anderson Cancer Center

Arup Kumar Sinha

The University of Texas MD Anderson Cancer Center

Jose Rodrigo Espinosa Fernandez

The University of Texas MD Anderson Cancer Center

Anjali James

The University of Texas MD Anderson Cancer Center

Keisuke Yamagishi

Sysmex Corp: Sysmex Kabushiki Kaisha

Tomoko Matsushima

Sysmex Corp: Sysmex Kabushiki Kaisha

Robert Schuetz

University of Hawai'i Cancer Center

Debu Tripathy 
The University of Texas MD Anderson Cancer Center

\section{Sachiyo Tada}

Sysmex Corp: Sysmex Kabushiki Kaisha

\section{Rubie S. Jackson}

AAMC: Anne Arundel Medical Center Inc

\section{Shinzaburo Noguchi}

Osaka University Faculty of Medicine Graduate School of Medicine: Osaka Daigaku Daigakuin Igakukei Kenkyuka Igakubu

\section{Seigo Nakamura}

Showa University - Hatanodai Campus: Showa Daigaku

\section{Jared D. Acoba}

University of Hawai'i Cancer Center

Naoto T Ueno ( $\square$ nueno@mdanderson.org )

The Univeristy of Texas MD Anderson Cancer Center https://orcid.org/0000-0002-0166-7275

\section{Research Article}

Keywords: Breast cancer, 21-gene signature assay, 95-gene signature assay, Estrogen receptor-positive, Recurrence Score

Posted Date: May 13th, 2021

DOI: https://doi.org/10.21203/rs.3.rs-496843/v1

License: (c) (1) This work is licensed under a Creative Commons Attribution 4.0 International License. Read Full License 


\section{Abstract}

Purpose $A$ subset of patients with intermediate 21-gene signature assay recurrence score may benefit from adjuvant chemoendocrine therapy, but a predictive strategy is needed to identify such patients. The 95-gene signature assay was tested to stratify patients with intermediate RS into high (95GC-H) and low (95GC-L) groups that were associated with invasive recurrence risk.

Methods Patients with ER-positive, HER2-negative, node-negative breast cancer and RS 11-25 who underwent definitive surgery and adjuvant endocrine therapy without any cytotoxic agents were included. RNA was extracted from archived formalin-fixed, paraffin-embedded samples, and 95-gene signature was calculated.

Results Two hundred six patients had RS of 11-25 (95GC-L, N = 163; 95GC-H, N = 43). In Cox proportional hazards model, 95GC-H was significantly associated with shorter time to recurrence than was 95GC-L (HR $5.94 ; 95 \% \mathrm{Cl} 1.81-19.53 ; \mathrm{P}=0.005)$. The correlation between 95 -gene signature and 21-gene signature assay scores was not strong (correlation coefficient $r=0.27$ ), which might suggest that 95-gene signature reflects biological characteristics differing from what 21-gene signature shows.

Conclusions The 95-gene signature stratifies patients with ER-positive, HER2-negative, node-negative invasive breast cancer and intermediate RS of 11-25 into high and low groups that are associated with recurrence risk of invasive disease. Further retrospective analysis in the prospectively-accrued TAILORx population is warranted to confirm that 95-gene signature can identify patients who would benefit from adjuvant chemoendocrine therapy.

\section{Introduction}

The 21-gene signature assay (or 21-gene recurrence assay, Oncotype DX®, Exact Sciences Corporation, Madison, $\mathrm{WI}$ ) measures 21 genes by quantitative reverse transcriptase-PCR using formalin-fixed, paraffinembedded (FFPE) tissues to determine a Recurrence Score (RS). This RS estimates the likelihood of distant metastasis at 10 years from the date of diagnosis and conventionally stratifies patients into three risk groups: low (RS < 18), intermediate (RS 18-30), and high (RS > 30) [1]. Consideration of 21-gene signature assay RS scores has been incorporated into guidelines from the American Society of Clinical Oncology, National Comprehensive Cancer Network, and European Society of Medical Oncology [2-4]. Currently, chemotherapy in addition to endocrine therapy is strongly recommended for patients with high RS $[2,3]$. The benefit of adding chemotherapy to endocrine therapy is thought to be minimal in those with low RS, a practice supported by results of TAILORx trial: For patients with RS of 0-10, the 5-year invasive disease-free survival rate was $93.8 \%$ (95\% confidence interval [Cl] 92.4-94.9), and the 5-year distant recurrence-free survival rate was $99.3 \%$ (95\% Cl 98.7-99.6)[5]. Further, the TAILORx trial demonstrated that adjuvant endocrine and chemoendocrine therapies had similar efficacy in patients with hormone receptor-positive, HER2-negative, node-negative breast cancer with RS of 11-25 (hazard ratio [HR] of invasive disease-free survival after endocrine vs. chemoendocrine therapies, $1.08 ; 95 \% \mathrm{Cl} 0.94-1.24 ; P=$ 
0.26) [6]. However, in that study, the estimated invasive disease-free survival rate at 9 years in patients with RS of $11-25$ treated with endocrine therapy was $83.3 \% \pm 0.9 \%$ and approximately $17 \%$ of intermediate-RS patients may have an event within 9 years. This fact suggests that there must be a subset of patients with intermediate RS of 11-25 who may benefit from adjuvant chemoendocrine therapy. A predictive strategy to identify such patients is an unmet need. The ability to predict chemoendocrine therapy benefit in the setting of intermediate RS is limited particularly in postmenopausal or older women [7].

The 95-gene-based signature (95GC, Curebest ${ }^{\mathrm{TM}}$ 95GC Breast, Sysmex Corporation, Kobe, Japan) was developed using a DNA microarray to predict the risk of recurrence of ER-positive, node-negative primary breast cancer in 549 patients who have undergone definitive surgery and adjuvant endocrine therapy from the public data sets (GSE2034, GSE2990, GSE4922, GSE6532, GSE7390, GSE9195) [8]. The 95 genes were mathematically selected from approximately 20,000 human genes without human bias, which is distinct from 21-gene signature and 95 genes selected are mutually exclusive of the 21 genes. Given this fact, 95-gene signature is able to observe the biological characteristics different from 21-gene signature. Whereas 21-gene signature assay stratifies patients into three risk categories, 95-gene signature stratifies patients into two risk categories: 95GC-Low (95GC-L) and 95GC-High (95GC-H). In a 105-patient cohort, the 5 -year recurrence-free survival (RFS) rates were $96.7 \%$ for $95 \mathrm{GC}$-L and $58.1 \%$ for 95GC-H $(P<0.001)$ [8]. In an independent 75-patient cohort, the 5-year RFS rates were $96.5 \%$ for $95 \mathrm{GC}-\mathrm{L}$ and $79.1 \%$ for $95 \mathrm{GC}-\mathrm{H}(P=0.0017)$ [9]. Another retrospective study with a large cohort compared 95-gene signature and the 21-gene classifier of Recurrence Online, which is comparable to 21-gene signature assay $[10,11]$. Among the 459 patients in that study, 174 (37.9\%) were classified into 95GC-H and 285 patients $(62.1 \%)$ were classified into 95GC-L. RFS was significantly better in the 95GC-L group than in the 95GC-H group (log rank $P=5.5 \mathrm{e}-10)$. Based on the 21-gene classifier, 81 of the 459 patients $(17.6 \%)$ had intermediate scores. Those 81 patients were stratified using 95GC: 38 patients (46.9\%) as 95GC-L and 43 patients $(53.1 \%)$ as $95 \mathrm{GC}-\mathrm{H}$. RFS was significantly better in the 95GC-L group than in the 95GC-H group (log rank $P=0.002$ ). Those results suggest that $95 \mathrm{GC}$ might have utility for classifying patients with intermediate 21-gene signature assay RS into high- and low-risk groups. However, because the study used Recurrence Online to determine the estimated recurrence possibility by 21-gene signature, there is a need for validation using 21-gene signature assay and 95-gene signature in an independent patient cohort.

Our hypothesis is that the 95-gene signature can stratify patients with ER-positive, HER2-negative, nodenegative, invasive breast cancer and an intermediate 21-gene signature assay RS of 11-25 into binary recurrence risk categories.

\section{Methods}

\section{Study population}

This retrospective chart review with linked tissue analysis was approved by the Institutional Review Boards at the five participating institutions in the USA and Japan: The University of Texas MD Anderson 
Cancer Center (protocol number: PA15-0905), University of Hawai'i Cancer Center (protocol number: RA2017-021), Medical College of Wisconsin (protocol number: PRO00029366), Anne Arundel Medical Center (protocol number: 1056834), and Showa University (protocol number: 2383). A waiver of informed consent was granted based on the study's retrospective nature. We reviewed the institutional databases to identify patients with ER-positive, HER2-negative, node-negative invasive breast cancer who had 21gene signature assay data available and who had undergone definitive surgery between April, 2005 and May, 2018 and adjuvant endocrine therapy without any cytotoxic agents. We included only patients for whom archival FFPE tissue from definitive surgery was available. We excluded patients with pathological T4, pathological node-positive, distant metastatic disease, and male patients. Nodal micrometastasis was allowed. We included patients with RS of 11-25 according to TAILORx intermediate group.

\section{Data collection}

From the database, we extracted the 21-gene signature assay RS, age at diagnosis, menopausal status at diagnosis, histological type (ductal, lobular, or others), pathological T stage, progesterone receptor (PR) status, nuclear grade, and lymphovascular invasion status. ER and PR positivity were defined as tumors with $>1 \%$ of the cells positive using immunohistochemistry (IHC) staining. HER2 positivity was defined as a HER2/CEP17 fluorescence in situ hybridization ratio of $\geq 2.0$ and/or an IHC staining score of 3+ [12]. At the MD Anderson Cancer Center, Breast Medical Oncology database (Protocol number: 2004 - 0541) was used to identify the eligible patients.

\section{Sample handling and processing}

Archival FFPE tissue from either presurgical biopsy or resection specimens was prepared locally and sent to Sysmex Corporation (Kobe, Japan) under a Research Agreement. RNA was extracted from archival FFPE tissues. RNA was used for generation of second-strand CDNA, and the generated cDNA was amplified, then biotinylated and fragmented with an Ovation $\circledast$ FFPE WTA System (Tecan Genomics, Inc., Redwood City, CA), followed by hybridization to a GeneChip ${ }^{\text {TM }}$ Human Genome U133 Plus 2.0 array (Thermo Fisher Scientific Inc., Waltham, MA) overnight (for 18 hours) according to the manufacturer's protocol. Finally, the hybridized DNA microarray was fluorescence stained with GeneChip ${ }^{\text {TM }}$ Fluidics Station 450Dx v.2 and scanned with the GeneChip ${ }^{\text {TM }}$ Scanner 3000Dx v.2 (both from Thermo Fisher Scientific).

The microarray mRNA expression data for 95 genes were used for 95-gene signature analysis. The list of probes set IDs is shown in Table S1. First, total RNA, including mRNA, was extracted from FFPE tissue by using the RNeasy FFPE Kit (QIAGEN, Hilden, Germany). Next, cDNA was amplified from the mRNA using the Ovation ${ }^{\circ}$ FFPE WTA System (Tecan Genomics) and then biotin labeled using the Encore ${ }^{\circledR}$ Biotin Module (Tecan Genomics). For microarray analysis, the GeneChip Hybridization, Wash, and Stain Kit; GeneChip $^{\text {TM }}$ Hybridization Control Kit; GeneChip ${ }^{\text {TM }}$ Human Genome U133 Plus 2.0 Array; and GeneChip ${ }^{\text {TM }}$ System 3000Dx v.2 (Thermo Fisher Scientific) were used. 
After obtaining the microarray data, quality control of data was performed using Expression Console ${ }^{\mathrm{TM}}$ software (Thermo Fisher Scientific). Only data satisfying the internal standards were subjected to 95gene signature analysis. Using the 95-gene signature algorithm, a 95-gene signature score (about 0.1000 to 0.1000 ) was calculated from the expression levels of 95 genes on the microarray normalized by the ref-RMA method, and cases were classified into 95GC-H $(>0.0000)$ or 95GC-L $(\leq 0.0000)$ groups. For details on the method of calculating the 95-gene signature score, refer to U.S. patent no. US20110263444A1.

\section{Statistical analysis}

Standard descriptive statistics and frequency tabulation were used to summarize data. The chi-square test and Fisher's exact test were used to evaluate the association between two categorical variables. The Kruskal-Wallis test was used to compare the distributions of continuous variables among different groups. Univariate and cox regression models were used to investigate the association between each variable and time to recurrence (TTR). TTR was defined as the time from surgery to invasive disease recurrence or breast cancer-specific death. Patients who had not experienced recurrence or death were censored at the time of last follow-up. A Kaplan-Meier estimate with a log-rank test was used to compare TTR by group. Scatter plots were used to show the distribution of 95-gene signature and 21-gene signature assay scores. Pearson's correlation coefficient was used to assess the association between 95gene signature score and 21-gene signature assay score. All analyses were carried out using STATA 14 software (StataCorp, College Station, TX).

\section{Results}

\section{Patient characteristics}

A total of 229 patients were initially selected as meeting the inclusion criteria. Among them, total of 23 patients did not meet microarray quality control and were excluded, resulting in a total of 206 patients with RS of 11-25 for analysis. We classified 163 patients (79.1\%) as 95GC-L; 43 patients (20.9\%), as 95GC-H. There were no statistical differences in age, menopausal status, nuclear grade or PR status between the 95GC-H and 95GC-L groups (Table 1). The 95GC-H group had higher T stage tumors than did the 95GC-L group $(P=0.046)$. 
Table 1

Baseline patient characteristics for the 206 patients with RS 11-25

\begin{tabular}{|c|c|c|c|}
\hline & $\begin{array}{l}\text { 95GC-Low }(N=163) \\
\text { n (\%) }\end{array}$ & $\begin{array}{l}\text { 95GC-High }(N=43) \\
n(\%)\end{array}$ & $P$-value \\
\hline Age & & & 0.61 \\
\hline & $56(34.4)$ & $13(30.2)$ & \\
\hline$>50$ years & $107(65.6)$ & $30(69.8)$ & \\
\hline Menopausal status & & & 0.93 \\
\hline Premenopausal & $58(35.6)$ & 15 (34.9) & \\
\hline Postmenopausal & $105(64.4)$ & $28(65.1)$ & \\
\hline T Stage & & & 0.046 \\
\hline & $122(74.8)$ & $24(55.8)$ & \\
\hline T1 & 38 (23.3) & $17(39.5)$ & \\
\hline T3 & $2(1.2)$ & $1(2.3)$ & \\
\hline Unknown & $1(0.6)$ & $1(2.3)$ & \\
\hline Histology & & & 0.02 \\
\hline & $96(58.9)$ & $27(62.8)$ & \\
\hline Lobular & $25(15.3)$ & $0(0)$ & \\
\hline Other & $42(25.8)$ & $16(37.2)$ & \\
\hline Nuclear grade & & & 0.07 \\
\hline & $64(39.3)$ & $13(30.2)$ & \\
\hline I & $84(51.5)$ & $21(48.8)$ & \\
\hline III & $14(8.6)$ & $9(20.9)$ & \\
\hline Unknown & $1(0.6)$ & $0(0)$ & \\
\hline PR status & & & 0.79 \\
\hline
\end{tabular}




\begin{tabular}{|c|c|c|c|}
\hline $\begin{array}{l}\text { Negative } \\
\text { Positive }\end{array}$ & $\begin{array}{l}\text { 95GC-Low }(N=163) \\
\text { n (\%) }\end{array}$ & $\begin{array}{l}\text { 95GC-High }(N=43) \\
\text { n (\%) }\end{array}$ & $P$-value \\
\hline & $17(10.4)$ & $5(11.6)$ & \\
\hline & $146(89.6)$ & $38(88.4)$ & \\
\hline RS, median (range) & $19(11-25)$ & $20(15-25)$ & 0.1 \\
\hline
\end{tabular}

\section{Recurrence analysis}

Median follow-up was 64.5 months. Among patients with RS of 11-25, TTR was significantly longer in the 95GC-L group than in the 95GC-H group $(P<0.001)(\mathrm{Fig} .1 \mathrm{~A})$. The univariate Cox proportional hazards models revealed that among patients with RS of $11-25,95 \mathrm{GC}-\mathrm{H}$ was significantly associated with worse TTR than was 95GC-L (HR 5.94; 95\% Cl 1.81-19.53; $P=0.005)$ and no other factors are significantly associated with TTR (Table 2). 
Table 2

Cox regression analysis for TTR for the 206 patients with RS 11-25

\begin{tabular}{|c|c|c|}
\hline & $\mathrm{HR}(95 \% \mathrm{Cl})$ & $P$-value \\
\hline \multicolumn{3}{|l|}{ Age } \\
\hline & Reference & 0.37 \\
\hline & $1.92(0.42-8.81)$ & \\
\hline \multicolumn{3}{|l|}{ Menopausal status } \\
\hline Premenopausal & Reference & 0.38 \\
\hline Premenopausal & $1.89(0.41-8.72)$ & \\
\hline \multicolumn{3}{|l|}{ T Stage } \\
\hline & Reference & 0.16 \\
\hline T2 and T3 & $2.36(0.74-7.5)$ & \\
\hline \multicolumn{3}{|l|}{ Histology } \\
\hline & Reference & 0.72 \\
\hline Ductal & $1.63(0.34-7.87)$ & $1.63(0.34-7.8 /)$ \\
\hline Other & $1.63(0.42-6.34)$ & \\
\hline \multicolumn{3}{|l|}{ Nuclear grade } \\
\hline & Reference & \\
\hline I & $5.34(0.68-42.7)$ & 0.13 \\
\hline III & $5.0(0.45-55.3)$ & \\
\hline \multicolumn{3}{|l|}{ PR status } \\
\hline & Reference & 0.87 \\
\hline \multicolumn{3}{|l|}{ Negative } \\
\hline Positive & $1.18(0.15-9.14)$ & \\
\hline 95GC classification & & \\
\hline
\end{tabular}




\begin{tabular}{|lll|}
\hline & HR $(95 \% \mathrm{Cl})$ & $P$-value \\
\hline Low & Reference & 0.005 \\
\hline High & $5.94(1.81-19.53)$ & \\
\hline Abbreviations: PR, progesterone receptor; 95GC, Curebest & \\
\hline
\end{tabular}

Next, we analyzed separate subgroups of patients aged $\leq 50$ years and patients aged $>50$ years. For patients with RS $11-25$, only among patients with age $>50$ years, the $95 \mathrm{GC}-\mathrm{H}$ group had significantly shorter TTR than did the 95GC-L group $(P=0.004)$ (Fig. S1). The difference was not significant in patients aged $\leq 50$ years $(P=0.09)$.

\section{Correlation between 21-gene signature assay and 95-gene signature}

The correlation between 21-gene signature assay and 95-gene signature scores is shown in Fig. 2. Among the 206 patients with RS of 11-25, the correlation coefficient ( $r$ ) was 0.2 (Fig. 2A). The distribution of scores for 95GC-H and 95GC-L was wide in both plots regardless of 21-gene signature assay score.

\section{Discussion}

In this study, we demonstrated that 95-gene signature can stratify patients with ER-positive, HER2negative, node-negative invasive breast cancer and intermediate RS of 11-25 into two risk categories, low and high, in terms of TTR. We also showed lack of a strong correlation between 95-gene signature score and 21-gene signature assay score, which might suggest that 95-gene signature reflects biological characteristics differing from what 21-gene signature shows.

Among patients with intermediate RS of 11-25, the score range used in the TAlLORx trial, the risk of recurrence in the 95GC-H group was significantly high compared to that of the 95GC-L group (HR 5.94; $95 \% \mathrm{Cl} 1.81-19.53 ; P=0.005$ ) [6]. None of the other clinicopathological factors analyzed were associated with TTR. Interestingly, the correlation between individual 95-gene signature and 21-gene signature assay scores was not strong (Fig. 2). The 95-gene signature classifier assesses 95 genes totally exclusive of the genes used to create the 21-gene signature assay RS, and this weak correlation suggests that the ability of 95-gene signature is biologically independent of that of 21-gene signature assay [8].

An initial study of the 95-gene signature showed its prognostic utility in ER-positive, node-negative breast cancer [8]. A follow-up study of 459 patients consisting of a cohort of 148 patients from a university hospital in Japan and a cohort of 311 patients from public databases (GSE17705, GSE12093) tested the prognostic ability of 95-gene signature in patients with ER-positive, node-negative breast cancer and intermediate estimated RS of 18-30 based on the Recurrence Online 21-gene classifier [11]. The 95GC-L group had a significantly better RFS rate than did the $95 \mathrm{GC}-\mathrm{H}$ group $(P=0.002)$. This is the first study to investigate 95 -gene signature in the context of actual 21-gene signature assay. 
The TAILORx trial demonstrated that endocrine and chemoendocrine therapy did not significantly differ in terms of invasive disease-free survival in patients with hormone receptor-positive, HER2-negative, nodenegative breast cancer and RS of 11-25 (HR [endocrine vs. chemoendocrine therapy], $1.08 ; 95 \% \mathrm{Cl} 0.94-$ $1.24 ; P=0.26)[6]$. In that study, the estimated invasive disease-free survival rate at 9 years in patients with RS of $11-25$ treated with endocrine therapy was $83.3 \% \pm 0.9 \%$; thus, approximately $17 \%$ of intermediate-RS patients may have an event within 9 years and could potentially have a survival benefit from adjuvant chemotherapy. Certain aspects of the TAILORx trial should be noted. First, the median tumor size in the study was $1.5 \mathrm{~cm}(\mathrm{~T} 1)$, and the high proportion of relatively small tumors might have affected the results. There might not have been significant survival benefit from additional chemotherapy in part because of a favorable baseline characteristics seen among patients with T1 tumors. In contrast, among our study cohort with intermediate defined as RS $11-25,28 \%$ of patients had non-T1 disease (T2, $55 ; \mathrm{T} 3,3)$, which might have led to a significant difference in survival between the 95GC-H and 95GC-L groups.

Our findings suggest that 95-gene signature is associated with the risk of recurrence in patients with intermediate RS. Another notable finding of our study was that 95-gene signature successfully divided patients aged $>50$ years into high- and low-risk groups. The TAILORx trial did not have power enough to prove whether aged $>50$ years had a survival benefit from chemoendocrine therapy; however, by using the 95-gene signature, it may be possible to identify a population who would have a benefit. There is also a study showing that $95 \mathrm{GC}-\mathrm{H}$ group had a significantly higher partial response rate after neoadjuvant chemotherapy than $95 \mathrm{GC}-\mathrm{L}$ group $(P=0.003)$. This result might support the potential capability to predict response to chemotherapy [13]. The 95-gene signature classification was not significant among patients aged $\leq 50$ years, which may be attributable to the small sample size of that population. Recently, Sparano et al. showed that a new tool (RSCline), which integrates the 21-gene recurrence score and the clinicopathological features of histologic tumor grade, tumor size, and patient age at surgery, could provide more individualized estimation of survival benefit from adding adjuvant chemotherapy to endocrine therapy [14].

There are several limitations of this study. First, this is a retrospective study, and the ability of 95-gene signature to identify patients with intermediate RS who can benefit from adjuvant chemoendocrine therapy is still unknown. Second, our follow-up period was relatively short compared with that of the TAILORx trial; further study is needed. Third, subgroup analysis particularly by age was not fully performed because of the limited number of events in each subgroup. Forth, although all of the clinicians followed clinical practice guidelines, each treating physician decided on the entire treatment plans, and we do not have information about type of surgery, radiation therapy, or adjuvant systemic therapy, which could have affected the final results. Fifth, we included patients with node-negative disease, and the recent presentation about the RxPONDER trial at the 2020 San Antonio Breast Cancer Symposium led us to decide that testing the $95 \mathrm{GC}$ in patients with node-positive breast cancer was necessary [15].

\section{Conclusions}


Our results support that the the 95-gene signature stratifies patients with ER-positive, HER2-negative, node-negative invasive breast cancer and intermediate RS of 11-25 into high and low groups that are associated with recurrence risk of invasive disease. Further retrospective analysis in the prospectivelyaccrued TAILORx population is warranted to confirm that 95-gene signature can identify patients who would benefit from adjuvant chemoendocrine therapy.

\section{Declarations}

\section{Acknowledgements}

Editorial assistance was provided by Sunita Patterson and Donald R Norwood of Scientific Publication Services, Research Medical Library, The University of Texas MD Anderson Cancer Center. We also thank Kirk Y. Hirata and Christine Nakamoto of Pathology, The Queen's Medical Center for collection archival tissue samples.

\section{Funding}

This work was supported by the Morgan Welch Inflammatory Breast Cancer Research Program; a grant from the State of Texas Rare and Aggressive Breast Cancer Research Program; the MD Anderson's Cancer Center Support Grant from the National Cancer Institute (CA016672).

\section{Compliance with ethical standards}

\section{Conflict of interest}

K.Y., T.M., and S.T. are employees of Sysmex Corporation (Curebest ${ }^{\mathrm{TM}}$ 95GC Breast service provider). Y.N. holds a joint patent on Curebest ${ }^{\mathrm{TM}}$ 95GC Breast with Sysmex Corporation, receive research funds from Sysmex and AstraZeneca, and received a lecture fee of 100,000 yen a year from Sysmex Corporation, AstraZeneca and Takeda. S.N. has received honoraria and research grants from Sysmex Corporation and has been an advisor for Sysmex Corporation and holds a joint patent on Curebest ${ }^{\mathrm{TM}}$ 95GC Breast with Sysmex. N.T.U. has research grants with Sysmex Corporation and with Genomic Health.

\section{Ethics approval}

This retrospective chart review with linked tissue analysis was approved by the central Institutional Review Boards at the five participating institutions in the USA and Japan: The University of Texas MD Anderson Cancer Center (protocol number: PA15-0905), University of Hawai'i Cancer Center (protocol number: RA-2017-021), Medical College of Wisconsin (protocol number: PR000029366), Anne Arundel Medical Center (protocol number: 1056834), and Showa University (protocol number: 2383). A waiver of informed consent was granted based on the study's retrospective nature.

\section{Informed consent}

For this type of study, formal consent is not required. 


\section{References}

1. Paik S, Shak S, Tang G, Kim C, Baker J, Cronin M, Baehner FL, Walker MG, Watson D, Park T, Hiller W, Fisher ER, Wickerham DL, Bryant J, Wolmark N (2004) A multigene assay to predict recurrence of tamoxifen-treated, node-negative breast cancer. The New England journal of medicine, 351(27):28172826.10.1056/NEJMoa041588.

2. Harris L, Fritsche H, Mennel R, Norton L, Ravdin P, Taube S, Somerfield MR, Hayes DF, Bast RC, Jr. (2007) American Society of Clinical Oncology 2007 update of recommendations for the use of tumor markers in breast cancer. Journal of clinical oncology : official journal of the American Society of Clinical Oncology, 25(33):5287-5312.10.1200/jco.2007.14.2364.

3. National Comprehensive Cancer Network (NCCN) Clinical practice guidelines in oncology: breast cancer. V2.2015 [http://www.nccn.org/professionals/physician_gls/f_guidelines.asp]

4. Aebi S, Davidson T, Gruber G, Castiglione M (2010) Primary breast cancer: ESMO Clinical Practice Guidelines for diagnosis, treatment and follow-up. Annals of oncology : official journal of the European Society for Medical Oncology / ESMO, 21 Suppl 5:v9-14.10.1093/annonc/mdq159.

5. Sparano JA, Gray RJ, Makower DF, Pritchard KI, Albain KS, Hayes DF, Geyer CE, Dees EC, Perez EA, Olson JA, Zujewski J, Lively T, Badve SS, Saphner TJ, Wagner LI, Whelan TJ, Ellis MJ, Paik S, Wood WC, Ravdin P, Keane MM, Gomez Moreno HL, Reddy PS, Goggins TF, Mayer IA, Brufsky AM, Toppmeyer DL, Kaklamani VG, Atkins JN, Berenberg JL, Sledge GW (2015) Prospective Validation of a 21-Gene Expression Assay in Breast Cancer. New England Journal of Medicine, 373(21):20052014.10.1056/NEJMoa1510764.

6. Sparano JA, Gray RJ, Makower DF, Pritchard KI, Albain KS, Hayes DF, Geyer CE, Dees EC, Goetz MP, Olson JA, Lively T, Badve SS, Saphner TJ, Wagner LI, Whelan TJ, Ellis MJ, Paik S, Wood WC, Ravdin PM, Keane MM, Gomez Moreno HL, Reddy PS, Goggins TF, Mayer IA, Brufsky AM, Toppmeyer DL, Kaklamani VG, Berenberg JL, Abrams J, Sledge GW (2018) Adjuvant Chemotherapy Guided by a 21Gene Expression Assay in Breast Cancer. New England Journal of Medicine, 379(2):111121.10.1056/NEJMoa1804710.

7. Sparano JA, Gray RJ, Ravdin PM, Makower DF, Pritchard KI, Albain KS, Hayes DF, Geyer CE, Dees EC, Goetz MP, Olson JA, Lively T, Badve SS, Saphner TJ, Wagner LI, Whelan TJ, Ellis MJ, Paik S, Wood WC, Keane MM, Gomez Moreno HL, Reddy PS, Goggins TF, Mayer IA, Brufsky AM, Toppmeyer DL, Kaklamani VG, Berenberg JL, Abrams J, Sledge GW (2019) Clinical and Genomic Risk to Guide the Use of Adjuvant Therapy for Breast Cancer. New England Journal of Medicine, 380(25):23952405.10.1056/NEJMoa1904819.

8. Naoi Y, Kishi K, Tanei T, Tsunashima R, Tominaga N, Baba Y, Kim SJ, Taguchi T, Tamaki Y, Noguchi S (2011) Development of 95-gene classifier as a powerful predictor of recurrences in node-negative and ER-positive breast cancer patients. Breast cancer research and treatment, 128(3):633641.10.1007/s10549-010-1145-z.

9. Shiino S, Kinoshita T, Aogi K, Ohsumi S, Takahashi M, Ito K-I, Oba T, Arihiro K, Shiroma N, Tsukamoto F, Yoshida M (2017) 185PThe first report of multicenter validation study of 95-gene classifier, a multi- 
gene prognostic assay of estrogen receptor positive and node negative breast cancer patients. Annals of Oncology, 28(suppl_5).10.1093/annonc/mdx362.035.

10. Gyorffy B, Benke Z, Lanczky A, Balazs B, Szallasi Z, Timar J, Schafer R (2012) RecurrenceOnline: an online analysis tool to determine breast cancer recurrence and hormone receptor status using microarray data. Breast cancer research and treatment, 132(3):1025-1034.10.1007/s10549-0111676-y.

11. Naoi Y, Kishi K, Tsunashima R, Shimazu K, Shimomura A, Maruyama N, Shimoda M, Kagara N, Baba Y, Kim SJ, Noguchi S (2013) Comparison of efficacy of 95-gene and 21-gene classifier (Oncotype DX) for prediction of recurrence in ER-positive and node-negative breast cancer patients. Breast cancer research and treatment, 140(2):299-306.10.1007/s10549-013-2640-9.

12. Wolff AC, Hammond ME, Hicks DG, Dowsett M, McShane LM, Allison KH, Allred DC, Bartlett JM, Bilous M, Fitzgibbons P, Hanna W, Jenkins RB, Mangu PB, Paik S, Perez EA, Press MF, Spears PA, Vance GH, Viale G, Hayes DF, American Society of Clinical O, College of American P (2013) Recommendations for human epidermal growth factor receptor 2 testing in breast cancer: American Society of Clinical Oncology/College of American Pathologists clinical practice guideline update. Journal of clinical oncology : official journal of the American Society of Clinical Oncology, 31(31):3997-4013.10.1200/JC0.2013.50.9984.

13. Tsunashima R, Naoi Y, Kishi K, Baba Y, Shimomura A, Maruyama N, Nakayama T, Shimazu K, Kim SJ, Tamaki Y, Noguchi S (2012) Estrogen receptor positive breast cancer identified by 95-gene classifier as at high risk for relapse shows better response to neoadjuvant chemotherapy. Cancer Letters, 324(1):42-47.https://doi.org/10.1016/j.canlet.2012.04.017.

14. Sparano JA, Crager MR, Tang G, Gray RJ, Stemmer SM, Shak S (2021) Development and Validation of a Tool Integrating the 21-Gene Recurrence Score and Clinical-Pathological Features to Individualize Prognosis and Prediction of Chemotherapy Benefit in Early Breast Cancer. Journal of Clinical Oncology, 39(6):557-564.10.1200/jco.20.03007.

15. Kalinsky K, Barlow WE, Meric-Bernstam F, Gralow JR, Albain KS, Hayes D, Lin N, Perez EA, Goldstein LJ, Chia S, Dhesy-Thind S, Rastogi P, Alba E, Delaloge S, Martín M, Gil MG, Arce-Salinas C, Brain E, Park IH, Pierga J-Y, Lluch AH, Vasquez MR, Borrego MR, Jung KH, Ferrero J-M, Schott A, Shak S, Sharma P, Lew DL, Miao J, Tripathy D, Hortobagyi G, Pusztai L (2021) Abstract GS3-00: First results from a phase III randomized clinical trial of standard adjuvant endocrine therapy (ET) +/chemotherapy (CT) in patients (pts) with 1-3 positive nodes, hormone receptor-positive (HR+) and HER2-negative (HER2-) breast cancer (BC) with recurrence score (RS) \&lt; 25: SWOG S1007 (RxPonder). Cancer Research, 81(4 Supplement):GS3-00-GS03-00.10.1158/1538-7445.Sabcs20-gs300 .

\section{Figures}




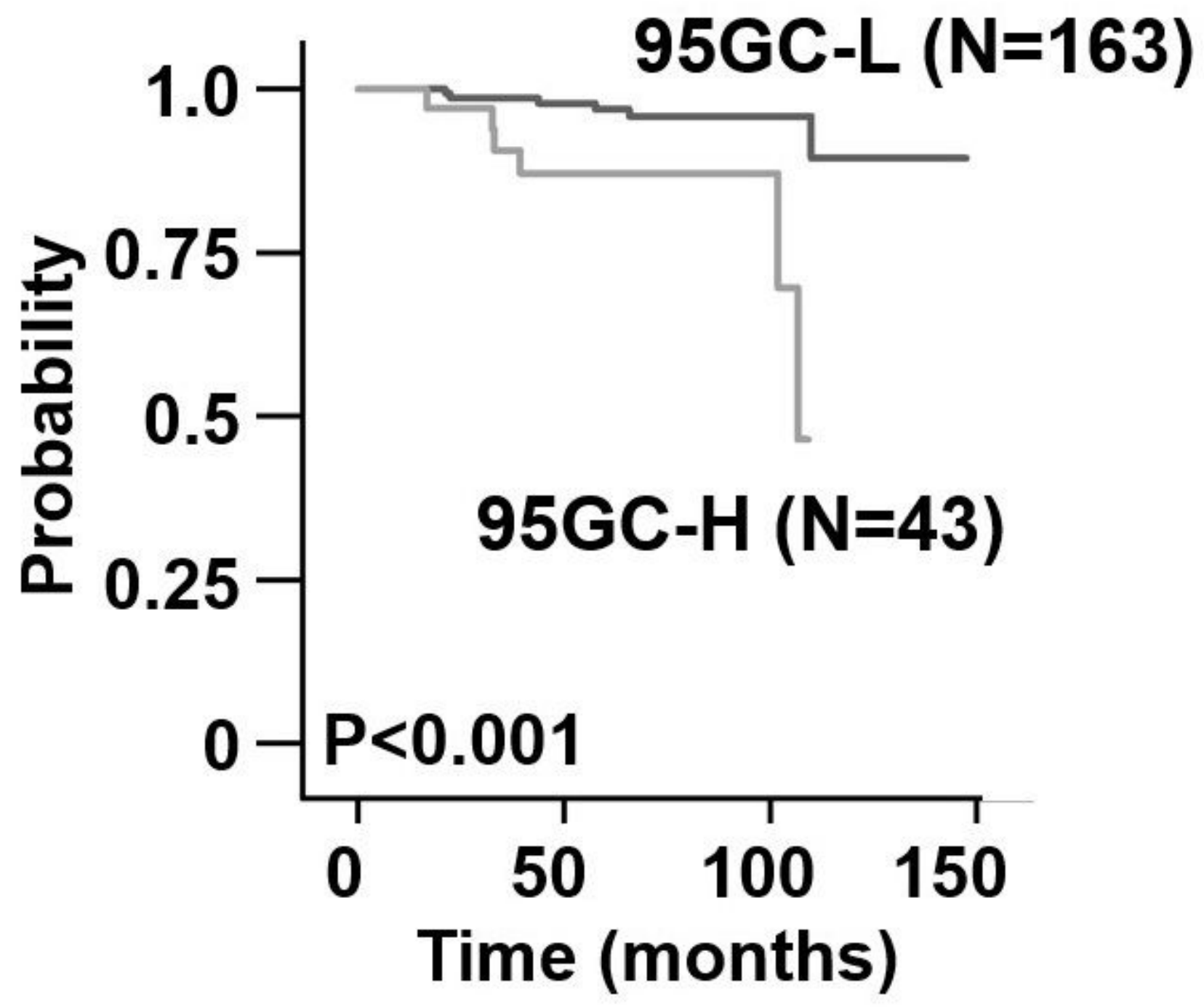

Figure 1

Time to recurrence (TTR) analysis TTR curve for patients with tumors classified as 95GC-L and as 95GC$\mathrm{H}$ for populations with "intermediate" 21-gene signature assay RS (11-25). 


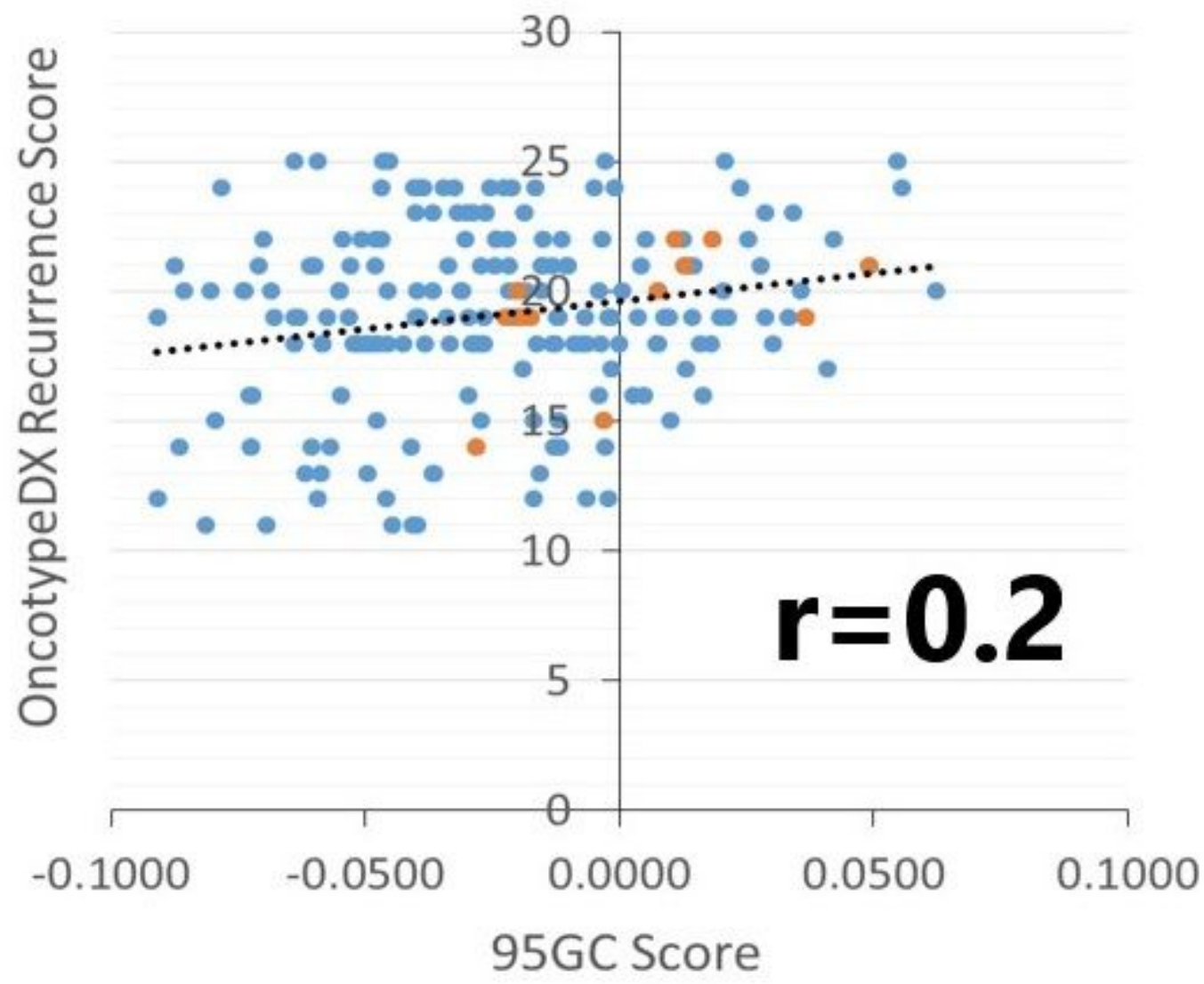

Figure 2

Correlation between 95GC and 21-gene signature assay scores Scatterplot representing scores for each patient with RS of 11-25. Orange dots represent a patient with recurrence.

\section{Supplementary Files}

This is a list of supplementary files associated with this preprint. Click to download.

- SupplementaryFiguresRevision1.docx

- SupplementaryTablesRevision1.docx 